\title{
Rutin reduces oxidative stress in animals with renovascular hypertension
}

\author{
Rayssa Duarte*, Alynne Carvalho, Danilo Gadelha, Valdir Braga \\ From 5th Congress of the Brazilian Biotechnology Society (SBBIOTEC) \\ Florianópolis, Brazil. 10-14 November 2013
}

\section{Introduction}

Rutin has been shown be a potent antioxidant that restores impaired vascular reactivity and baroreflex sensitivity in hypertensive rats, mainly by decreasing oxidative stress.

\section{Objective}

This study aimed to evaluate the effect of rutin administration on the baroreflex and oxidative stress in serum of rats with renovascular hypertension (2K1C hypertension model) and their normotensive controls.

\section{Methods}

Twenty-four rats were divided into 4 groups: sham + saline, sham + rutin, $2 \mathrm{~K} 1 \mathrm{C}+$ saline and $2 \mathrm{~K} 1 \mathrm{C}+$ rutin. Six weeks after $2 \mathrm{~K} 1 \mathrm{C}$ surgery, animals presented hypertension compared to the control group $(142 \pm 2 \mathrm{mmHg}$ versus $121 \pm 2 \mathrm{mmHg}, \mathrm{n}=8, \mathrm{p}<0.05$ ), while there was no change in heart rate. After six weeks, animals were treated with saline or rutin $(30 \mathrm{mg} / \mathrm{kg} /$ day) by gavage for 14 days. The baroreflex sensitivity was evaluated using intravenous injection of phenylephrine $(8 \mathrm{mg} / \mathrm{kg})$ and sodium nitroprusside $(25 \mathrm{mg} / \mathrm{kg})$. Lipid peroxidation was measured in serum by thiobarbituric acid reactive species assay (TBRAS).

\section{Results}

Chronic treatment with rutin produced an improvement in baroreflex sensitivity in the $2 \mathrm{~K} 1 \mathrm{C}$ group, raising it to levels similar to those observed in the Sham + Saline group $\left(-2.55 \pm 0.15\right.$ vs. $-2.70 \pm 0.20 \mathrm{bpm} . \mathrm{mmHg}^{-1}$, respectively, $\mathrm{n}=6, \mathrm{p}=0.05)$ and higher compared to $2 \mathrm{~K} 1 \mathrm{C}+$ saline group $(-2.55 \pm 0.15$ vs. $-1.74 \pm 0.10 \mathrm{bpm}$. $\left.\mathrm{mmHg}^{-1}, \mathrm{n}=6 ; \mathrm{p}=0.05\right)$. Serum levels of lipid peroxidation in $2 \mathrm{~K} 1 \mathrm{C}$ rats were higher than in the sham group

Universidade Federal da Paraiba (UFPB), João Pessoa, Brazil
$(5.29 \pm 0.93$ vs. $4.00 \pm 0.01 \mathrm{nmol}$ de $\mathrm{MDA} / \mathrm{ml}$ respectively, $\mathrm{n}=6, \mathrm{p}<0.05)$. Chronic administration of rutin reduced serum levels of lipid peroxidation in hypertensive rats when compared to $2 \mathrm{~K} 1 \mathrm{C}+$ saline group $(2.24 \pm 5.29$ vs. $0.93 \pm 0.55 \mathrm{nmol}$ de $\mathrm{MDA} / \mathrm{ml}$, respectively, $\mathrm{p}<0.05$ ). No changes were found in the sham group.

\section{Conclusion}

These results suggest that rutin restores baroreflex sensitivity and reduce oxidative stress in rats with renovascular hypertension.

Published: 1 October 2014

doi:10.1186/1753-6561-8-S4-P65

Cite this article as: Duarte et al:: Rutin reduces oxidative stress in animals with renovascular hypertension. BMC Proceedings 2014 8(Suppl 4):P65.
Submit your next manuscript to BioMed Central and take full advantage of:

- Convenient online submission

- Thorough peer review

- No space constraints or color figure charges

- Immediate publication on acceptance

- Inclusion in PubMed, CAS, Scopus and Google Scholar

- Research which is freely available for redistribution
() Biomed Central 